\title{
Public health and colonialism: a new or old problem?
}

Epidemiology is not alone as a discipline in facing awesome challenges. ${ }^{1}$ It would also be wrong to ascribe to epidemiology any particular failures; many disciplines have shared difficult times as the world around them is restructured. What is at stake for the entire spectrum of public health disciplines-from "hard" medicine to "soft" policy-is nothing more than a need to re-think their own role in the new global social order. Gradually, the enormity of the economic changes that have been pushed through by the neo-liberal project are becoming clear to the public health movement. $^{2}$

Knowing this, can we justify investment in ever more sophisticated "technical fixes" for what we know are socially created health problems? ? $^{3}$ Is the future of policy to make the new global division of labour ever more efficient when this leads to social inequalities that are themselves a determinant of ill health? ? $^{4}$ Is surgery's contribution to the global coronary heart disease epidemic only to conduct ever more bypass operations when it is the Western diet (now being sold worldwide) that needs to be confronted?

These are big questions and lead to the realisation that a re-think of the conception and practice of public health in the 21 st century is long overdue. Put starkly, is the public health movement going to bow down or stand up to the new unequal distribution of power known as globalisation? Or is it merely going to wallow in complexity? Whatever the answer, the times ahead require us to think carefully about language, the words we use to indicate our concepts and ideas.

In this context, the use of the term "colonialism" should be welcomed back into debate about public health. Although it grates and is probably a little crude, it points to a core truth about the social determinants of health. The forces that systematically mould and influence health are humanly factored, socially influenced and unequal. This is not to deny the immense strides in understanding about genetic or other biophysical mechanisms. On the contrary, the more such pathways are understood, the more important it is to appreciate the social factors that can make or manage them. The challenge laid down by the New Public Health - which is in fact rather old now (first referenced in 1911 !) - is that policy and human actions can make a considerable difference to health outcomes. This being the case, the grand sweep of historical forces once again become pertinent. We are so easily focused on minutiae in our professional and everyday lives that we cannot see the wood for the trees, to use that English phrase.

Like "class", the word "colonialism" resonates with meanings from an older social order, a period and centuries marked by great political tussles in which huge historical dynamics could be identified. The proponents of postmodernity sometime imply that these older words described a social reality that no longer exists. ${ }^{6}$ Colonialism, class, power, state intervention, etc, derive, they argue, from an obsolete lexicon. Differences among people are reduced to individual factors, chance or genetics. History itself, siren voices argue, has stopped, with the triumph of the West. ${ }^{7}$

Who could disagree that we live through a period of astonishing change? Yet the power of the information age - with its surfeit of data-enables us now to see the post-modern Emperor for what it is. ${ }^{8}$ Class, colonialism, social tension not only never went; they merely changed their clothes. The amazing gap between rich and poor within and between societies is well documented. There are
1.2 billion people living on US $\$ 1$ per day. ${ }^{9}$ Meanwhile, the top 200 billionaires doubled their wealth in 1994-98 and just three of their number have more wealth than the combined GNP of all least developed countries, a total of 600 million people. ${ }^{10}$ Michael Jordan, a US athlete, was paid US $\$ 20$ million for endorsing Nike trainers, more than the entire workforce was paid for making them. ${ }^{11}$ His wealth, their health? Should we be surprised that after huge gains in life expectancy in the 1970s, it is now slipping? Or that 800 million children globally are under-nourished or that 2 billion people exhibit effects of poor diet? ${ }^{12}$ Our era is not neo-colonial; it is more neo-mediaeval.

A new global class structure has quietly unfolded in which epidemiologists and all social researchers need to look beyond national or regional boundaries to see similarities of experience. The rich of Mumbai, India and Manchester, England may have more in common with each other than their neighbouring poor and the same may be true for the poor. If epidemiology is to grasp this reality as an explanatory tool, it must expand both its spatial units and conceptual boundaries, in the way it is already being asked to do in relation to the borders of environmental and human health. ${ }^{13}$ Social scientists studying food have for decades been pointing to gaps between developed and developing worlds. It is now time to look within as well as between. New comparative partnerships are the key to methodologies. Health realities need to be explored on four levels (local, national, regional and global) and new professional intersectoral collaboration are needed.

This is easy to write, but hard to do. Academic discourse has been put onto a treadmill of contracts and business. For 20 years, since a neo-liberal orthodoxy triumphed in Western politics and economic management, ${ }^{14}$ dissident voices have been hushed. The intellectual space for criticism diminished, in part because of funding, work schedules, etc, and in part because of specialisation and exhaustion. But civil society, in particular NonGovernmental Organisations (NGOs), is leading the way in rolling back this shroud. At Seattle, in December 1999, an unforeseen alliance of public interest groups came together to protest at the new order. Having failed to get even token reforms into the 1994 Uruguay Round of the General Agreement on Tariffs and Trade (GATT), they were left only with the right to protest. They brought to a halt the latest round of what Watkins memorably called "fixing the rules". ${ }^{15}$

Suddenly, space to debate is emerging. While the "realists" argued that globalisation cannot be stopped, the Seattle movements remind us that social reality is made not given. All who work to promote public health need to seize this chance and debate core ideas and themes. We need to be unashamedly partisan in promoting public, not just individual, health and to rediscover our roots in social medicine. We need to engage with thorny governance issues, siding with the health democrats over the control tendency. Our role is to promote policy integration over fragmentation, and to provide an evidence base for just and equitable public policy and practice. This can only be done by recognising not disguising the raw inequalities of power that were unfolded by the neo-liberal project geo-spatially, in both North and South, East and West.

TIM LANG

Centre for Food Policy, Wolfson Institute of Health Sciences, Thames Valley University, 32-38 Uxbridge Road, Ealing, London W5 2BS, United Kingdom 
1 Avilés LA. Epidemiology as discourse: the politics of development institutions in the Epidemiological Profile of El Salvador. 7 Epidemiol Commuinstitutions in the Epidemiologicd
nity Health 2001;55:164-71.

2 Lee K. The impact of globalization on public health. F Public Health Med 2000;22:253-62.

3 Lang T. Diet, health and globalisation: 5 key questions. Proc Nutr Soc 1999; 58:335-43.

4 Marmot M, Wilkinson RG, eds . Social determinants of health. Oxford: Oxford University Press, 1999.

5 Lang T. The public health impact of globalisation of food trade. In: Shetty P, McPherson K, eds. Diet, nutrition and chronic Disease: lessons from contrasting worlds. London: J Wiley, 1997:173-86.

6 Giddens A. The third way and its critics. London: Polity, 2000

7 Fukuyama F. The end of history and the last man. London: Hamish Hamilton, 1992
8 Castells $M$. The information age: economy, society and culture. Oxford: Blackwell, 1996.

9 UNDP. Human Development Report 2000. New York: United Nations Development Programme, 2000.

10 UNDP. Human Development Report 1999. New York: United Nations Development Programme, 1999.

11 Klein N. No logo. London: HarperCollins, 2000.

12 UNICEF. State of the world's children 1998. New York: United Nations Childrens Fund, 1998

13 McMichael AJ. Planetary overload: global environmental change and the health of the human species. Cambridge: Cambridge University Press, 1993.

14 Crockett R. Thinking the unthinkable. London: Fontana, 1995.

15 Watkins K. Fixing the rules. London: Catholic Institute for International Relations, 1992. 